\title{
Comparison of Efficacy of Shock Wave Lithotripsy in Different Age Groups
}

\author{
Şok Dalga Tedavisinin Etkinliğinin Farklı Yaş Gruplarında Karşılaştııılması
}

\author{
Mehmet IIlker Gökçe, Aykut Akıncı, Çağrı Akpınar, Adem Sancı, Vahid Talha Solak, Evren Süer \\ Ankara University Faculty of Medicine, Department of Urology, Ankara, Turkiye
}

\begin{abstract}
What's known on the subject? and What does the study add?
For the management of renal stones, shock wave lithotripsy (SWL) is advised by the European Association of Urology and American Urological Association guidelines. Efficacy of SWL in the elderly population was shown to be lower in some studies. However, these studies were not published recently and SWL devices and the technique has changed remarkably in the last decade. This study compares the efficacy of SWL in different age groups and the results showed no difference in the success rates.
\end{abstract}

\begin{abstract}
Objective: Shock wave lithotripsy (SWL) is a safe and effective treatment for renal stones. The success rate of SWL has been shown to be lower in the elderly populations. However, in these previous studies, the SWL devices and techniques were not compatible with the current devices and techniques. In this study, it was aimed to compare the success rates of SWL in different age groups and evaluate the effect of age on SWL outcomes. Materials and Methods: Data of 472 patients who have undergone SWL was evaluated. The patients were grouped into 3 age categories: 18-40 $(n=159), 41-64(n=180)$, and $\geq 65(n=133)$ years. Data regarding stone location, stone size, number of SWL sessions, and success rates were recorded. The groups were compared for success rates. Additionally, logistic regression analysis was performed to evaluate the effect of age on success rates of SWL treatment.

Results: The success rates in patients in age categories $18-40$ years, $41-64$ years and $\geq 65$ years were $75.4 \%, 75.6 \%$ and $69.1 \%$, respectively ( $p=0.37$ ). In the logistic regression analysis, age was not found to be associated with success rates. In the multivariate analysis, greater stone size [odds ratio (OR): $1.59,95 \%$ confidence interval $(\mathrm{Cl}): 1.10-4.24, \mathrm{p}=0.04]$ and lower pole location (OR: $1.65,95 \% \mathrm{Cl}: 1.110-5.327, \mathrm{p}=0.04)$ were found to be associated with lower success rates.

Conclusion: There were no significant differences in the rate of success of SWL treatment in different age groups. In patients over 65 years of age, SWL treatment should not be avoided with the assumption of lower success rates.
\end{abstract}

Keywords: Shock wave lithotripsy, age, stone free rate

Öz

Amaç: Böbrek taşlarının tedavisinde şok dalga tedavisi (SWL) güvenli ve etkin bir tedavi olarak kullanılmaktadır. Yaşlı popülasyonda SWL etkinliğinin daha düşük olabileceği belirtilmiştir. Ancak bu çalışmalarda güncel SWL cihazları ve tekniği kullanılmamıştır. Bu çalışmada, SWL etkinliğinin farklı yaş gruplarında karşılaştırılması ve yaşın SWL etkinliği üzerine olan etkisinin değerlendirilmesi amaçlanmıştır.

Gereç ve Yöntem: SWL yapılan 472 hastanın verileri değerlendirilmiştir. Hastalar yaş gruplarına göre; 18-40 ( $n=159)$, 41-64 ( $n=180)$ ve $\geq 65$ ( $n=133$ ) yaş olmak üzere 3 gruba ayrılmıştır. Hastalara ait taş yerleşimi, boyutu, SWL seans sayısı ve SWL başarı oranları kaydedilmiştir. Gruplar başarı oranları açısından karşılaştırılmıştır. Ayrıca SWL başarısına yaşın etkisini değerlendirmek için lojistik regresyon analizi yapılmıştır.

Bulgular: SWL başarı oranları 18-40 yaş, 41-64 yaş ve $\geq 65$ yaş gruplarında sırasıyla \%75,4, \%75,6 ve \%69,1 olarak saptanmıştır ( $p=0,37$ ). Lojistik regresyon analizinde SWL başarısı açısından hasta yaşı anlamlı bir parametre olarak bulunmamıştır. Çok değişkenli analizde taş boyutunun büyümesi [göreceli olasılıklar oranı (OR): 1,59, 95\% güven aralığı (GA): 1,10-4,24, $p=0,04$ ] ve alt kaliks yerleşimli olması (OR: 1,65, 95\% GA: 1,110-5,327, $p=0,04)$ daha düşük başarı oranları ile ilişkili olarak bulunmuştur.

Sonuç: Böbrek taşı nedeniyle SWL uygulanan hastalarda yaş grupları arasında SWL başarısı açısından anlamlı fark saptanmamıştır. $\geq 65$ yaş olan hastalarda SWL tedavisinden başarı oranlarının düşük olacağı düşünülerek kaçınılmamalıdır.

Anahtar Kelimeler: Şok dalga tedavisi, yaş, taşsızlık oranları

Correspondence: Mehmet İlker Gökçe MD, Ankara University Faculty of Medicine, Department of Urology, Ankara, Turkiye

Phone: +90 3125082081 E-mail: migokce@yahoo.com

Received: 20.03.2017 Accepted: 29.03.2017

Cite this article as: Gökçe Mi, Akıncı A, Akpınar Ç, Sancı A, Solak VT, Süer E. Comparison of Efficacy of Shock Wave Lithotripsy in Different Age Groups. J Urol Surg 2017;4:66-70.

बCopyright 2017 by the Association of Urological Surgery / Journal of Urological Surgery published by Galenos Publishing House. 


\section{Introduction}

Stone disease is an important health problem due to its effect on renal functions and quality of life of the patients $(1,2)$. Extracorporeal shock wave lithotripsy (ESWL), retrograde intrarenal surgery, and percutaneous nephrolithotomy are the available treatment modalities offered by the most recent European Association of Urology and American Urological Association guidelines for the treatment of patients with a nonlower pole stone of $<20 \mathrm{~mm}$ in diameter $(3,4)$.

ESWL has the advantages of being less invasive and resulting in lower complication rates compared to the endourology procedures. However, main drawback of ESWL is the lower success rates with higher re-treatment rates compared to retrograde intrarenal surgery and percutaneous nephrolithotomy $(5,6)$. Patient selection to provide highest success and lowest complication rates should be the main aim of the endourologist. Therefore, evaluation of parameters that affect outcomes of ESWL had been the subject of many studies and nomograms and scoring systems have been established $(7,8,9,10,11)$.

Besides, factors such as stone density, stone to skin distance, stone diameter, and age were also determined as prognostic parameters for ESWL outcomes. However, conflicting results have been reported on the effect of age. In some studies, age was found to have a negative effect on ESWL outcomes $(9,12,13)$. In a recent study, Ichiyanagi et al. (14) evaluated the effect of age on the time needed to establish stone clearance after ESWL and concluded that age had no effect on ESWL success but patients aged $\geq 80$ years might experience delayed stone clearance within the first 12 months after ESWL.

The success of the ESWL procedure also depends on the ESWL device and applied energy and shock wave frequency. The previous studies evaluating the effect of age on ESWL success rates are mainly performed about a decade ago with older generation ESWL devices and, in this study, we aimed to identify the effect of age on ESWL success with the currently accepted ESWL methodology.

\section{Materials and Methods}

We retrospectively evaluated data of 472 patients who underwent SWL treatment for renal stones $<20 \mathrm{~mm}$ in the largest diameter in our department from January 2011 to January 2016 and followed up for at least 12 months. Informed consent was taken from every patient prior to the treatment. Stone disease was diagnosed by use of renal ultrasonography (USG), plain abdominal radiography (KUB) and intravenous urography or non-contrast-enhanced computed tomography (NCT). In case of a positive urine culture, appropriate antibiotic therapy was prescribed and sterile urine was established. Demographic and stone-related characteristics were: age, gender, use of alpha blockers as medical expulsive therapy, size and location of the stone, and number of ESWL sessions. For medical expulsive therapy, tamsulosin, an alpha blocker, was prescribed.

Success of the procedure was evaluated using KUB and USG. In case of a radiolucent stone or a possible ancillary procedure, NCT was performed. ESWL success was defined as absence of a residual fragment $>2 \mathrm{~mm}$ in size (15). The patients were grouped into 3 age categories: 18-40 ( $n=159), 41-64(n=180)$, and $\geq 65$ $(n=133)$ years. The groups were compared for success rates.

ESWL was performed with ELMED Complit ESWL device (Elektronik ve Medikal Sanayi ve Ticaret A.Ş., Ankara, Turkiye). All patients were treated on an outpatient basis without anesthesia but sedation was applied with midazolam $0.1 \mathrm{mg} /$ $\mathrm{kg}$ intravenously when the patient could not tolerate the procedure. All treatment sessions were limited to 3000 shocks with frequency of 60-90 shocks per minute and power ramping was applied (started at $14 \mathrm{kV}$ and gradually increased to $21 \mathrm{kV}$ ). None of the patients were stented prior to the procedure.

\section{Statistical Analysis}

For statistical analysis, SPSS version 21 (IBM Corp, Armonk, NY, U.S.) was used. A p value of less than 0.05 was considered statistically significant. Comparisons between the groups were performed using chi-square tests for categorical variables and analysis of variance or Kruskal-Wallis $\mathrm{H}$ test were used for continuous variables, depending on the distribution of the data. Univariate and multivariate logistic regression analyses were conducted to identify variables predictive of success rates. Age is included as a continuous variable in the logistic regression analysis.

\section{Results}

The mean age of the population was $44.8 \pm 8.7$ years. The age groups were similar for the parameters of sex, mean stone size, stone location, use of alpha blockers, and number of ESWL sessions (Table 1).

The success rates in the $18-40$ years, $41-64$ years and $\geq 65$ years groups were $75.4 \%, 75.6 \%$ and $69.2 \%$, respectively and the difference between the groups was not statistically significant $(p=0.37)$. In case of ESWL failure, retrograde intrarenal surgery was the most common treatment modality for all groups. The number of cases with success and ancillary procedures are summarized in Table 2.

In the logistic regression analysis, age, sex, stone laterality, and use of medical expulsive therapy were not found to be associated with success rates. Stone size, stone location and number of ESWL sessions were found to be associated with success rates in 
Table 1. Characteristics of the patients in different age groups

\begin{tabular}{|c|c|c|c|c|}
\hline Parameters & Age $18-40(n=159)$ & Age $41-64(n=180)$ & Age $\geq 65(n=133)$ & $\mathbf{p}$ \\
\hline Male gender, n (\%) & $95(59.7)$ & $105(58.3)$ & $82(61.6)$ & 0.83 \\
\hline Stone size $(\mathrm{mm})$, mean $\pm \mathrm{SD}$ & $14.8 \pm 4.9$ & $14.1 \pm 4.2$ & $13.8 \pm 3.9$ & 0.72 \\
\hline Stone laterality, n (\%) & & & & 0.52 \\
\hline Right & $75(47.2)$ & $96(53.3)$ & $67(50.4)$ & \\
\hline Left & $84(52.8)$ & $84(46.7)$ & $66(49.6)$ & \\
\hline Stone location, n (\%) & & & & 0.99 \\
\hline Pelvis & $61(38.4)$ & $70(38.9)$ & $54(40.6)$ & \\
\hline Upper pole & $29(18.2)$ & $34(18.9)$ & $24(18)$ & \\
\hline Middle pole & $36(22.6)$ & $35(19.4)$ & $28(21.1)$ & \\
\hline Lower pole & $33(20.8)$ & $41(22.8)$ & $27(20.3)$ & \\
\hline Number of SWL sessions, median (range) & $2(1-3)$ & $2(1-3)$ & $2(1-3)$ & 0.77 \\
\hline \multirow[t]{2}{*}{ Use of medical expulsive therapy } & & $46(25.6)$ & $32(24.1)$ & 0.88 \\
\hline & $37(23.3)$ & & & \\
\hline
\end{tabular}

Table 2. Summary of success rates and ancillary procedures in different age groups

\begin{tabular}{|c|c|c|c|c|}
\hline Treatment outcome & Age 18-40 $(n=159)$ & Age $41-64(n=180)$ & Age $\geq 65(n=133)$ & $\mathbf{p}$ \\
\hline Success, n (\%) & $120(75.4)$ & $136(75.6)$ & $92(69.2)$ & 0.37 \\
\hline Failure, n (\%) & $39(24.6)$ & $44(24.4)$ & $41(30.8)$ & \\
\hline \multicolumn{5}{|l|}{ Ancillary procedures } \\
\hline Observation, n (\%) & $6(15.4)$ & $6(13.6)$ & $8(19.5)$ & 0.67 \\
\hline Retrograde intrarenal surgery, $\mathrm{n}(\%)$ & $27(69.2)$ & 35 (79.5) & $29(70.8)$ & \\
\hline Percutaneous nephrolithotomy, n (\%) & $6(15.4)$ & $3(6.9)$ & $4(9.7)$ & \\
\hline
\end{tabular}

the univariate analysis and the results are summarized in Table 3 . In the multivariate analysis, greater stone size (odds ratio (OR): 1.59, 95\% confidence interval $(\mathrm{Cl}): 1.10-4.24, \mathrm{p}=0.04)$ and lower pole location (OR: 1.65, 95\% Cl: 1.110-5.327, $\mathrm{p}=0.04$ ) were found to be associated with lower success rates.

Regarding the complication rates, macroscopic hematuria was the most common complication and detected in 30 (18.9\%), $41(22.8 \%)$, and 39 (29.3) patients in the 18-40 years, 41-64 years and $\geq 65$ years groups, respectively $(p=0.106)$. Perirenal hematoma was detected in 3 patients in the entire population (one patient in the 18-40 years group and the other 2 in the $\geq 65$ years group).

\section{Discussion}

ESWL is one of the main treatment options for the management of renal stones with a diameter $<20 \mathrm{~mm}$ in diameter and our results indicate that outcomes of ESWL are not affected by age. Treatment of stone disease in elderly patients can be complicated by presence of comorbidities and, ESWL is a good option in this population as it does not necessitate general anesthesia.

Decreased success rates in ESWL have been reported in previous studies. Abe et al. (16) evaluated the results of 2844 patients treated with ESWL in a 13-year period. The patients were evaluated 3 months after treatment. Stone-free rate in patients $>60$ years of age was detected to be $57 \%$ and this was significantly lower than in the younger age groups of $<19,20-$ 39, 40-59 which were 93\%, 74\%, and 61\%, respectively (16). In another study, Kimura and Sasagawa (17) also compared age groups of $\leq 39,40-49,50-59,60-69$, and $>70$ years in 601 patients. Stone-free rates were $87.4 \%, 84.4 \%, 75 \%, 71.1 \%$, and $66.3 \%$, respectively. The underlying mechanisms for the decreased success rates in the elderly population are not clear. Increased acoustic impedance due to age-related sclerosis in the renal parenchyma was blamed for decreased rate of fragmentation. Another factor hypothesized was the decreased expulsion rate of the fragments in the elderly population (14).

In a recent study, Ichiyanagi et al. (14) compared the success rates in SWL together with time to stone clearance in different 
Table 3. Results of univariate analysis for success rate following shock wave lithotripsy

\begin{tabular}{llll}
\hline Parameter & OR & $\mathbf{9 5 \%} \mathrm{Cl}$ & $\mathbf{p}$ \\
\hline Age & 1.107 & $0.685-1.139$ & 0.914 \\
Sex (male vs. female) & 1.131 & $0.617-1.487$ & 0.812 \\
Stone laterality & 1.006 & $0.481-1.119$ & 0.995 \\
Stone size & 2.155 & $1.348-5.170$ & 0.008 \\
Stone location (lower pole vs. other locations) & 2.004 & $1.226-4.398$ & 0.011 \\
Number of SWL sessions & 1.664 & $1.212-2.714$ & 0.044 \\
Use of medical expulsive therapy & 1.280 & $0.804-1.994$ & 0.772 \\
\hline
\end{tabular}

OR: Odds ratio, Cl: Confidence interval, SWL: Shock wave lithotripsy

age groups. The authors evaluated the results of 247 patients and classified patients into 10-year age groups. The stone-free rate at 3 months was $74.9 \%$ and increased over $90 \%$ in each age group after 18 months. The stone free-rate did not differ between the age groups, however, patients older than 80 years of age were proposed to have a delay for reaching the stone-free status (14). Similarly, we did not detect a significant difference in success rates between the age groups. The stone free rates in the elderly populations in studies by Abe et al. (16) and Kimura and Sasagawa (17) were lower than our results (57\% and 66.3\% vs. 69.2\%). This may be due to longer follow-up (at least 12 months) of patients in our study which condones the delayed stone expulsion in the elderly population.

Complications following ESWL have been shown to be higher in the elderly population. Dhar et al. (18) evaluated the results of 317 patients to determine the factors that affect the rate of subcapsular hematoma. Subcapsular hematoma was observed in $4.1 \%$ of the cases. The authors identified patient age as a factor associated with increased rate of subcapsular hematoma (18). Subcapsular hematoma was observed in only three patients in the current study which is significantly lower than the results of Dhar et al. (18). We believe that this is mainly due to the different ESWL techniques.

\section{Study Limitations}

Our study has important drawbacks. First of all, this is a retrospective study and the treatment success was evaluated with KUB or USG, which are not the gold standard imaging methods, in most of the patients. Also, we grouped the patients into three age groups. This is not a standardized method of age grouping but due to the relatively low number of patients, we could not make grouping with 10-year increments, which was the methodology in most of the studies on this subject. Another important drawback is the lack of information on stone to skin distance and stone attenuation which are the parameters associated with success of the procedure. We could not get information on these parameters since an important portion of the patients did not undergo NCT before treatment.

\section{Conclusion}

Our results reveal that SWL outcomes are not affected by aging. Success rates were shown to be affected by stone size and location in our study. These two parameters should be taken into account while deciding the treatment options in renal stone patients of all age groups. We believe that with the equivocal success rate and acceptable complication rates, ESWL should not be underestimated as a treatment alternative in elderly renal stone patients.

\section{Ethics}

Ethics Committee Approval: Ethics committee approval was not applied because of retrospective design.

Informed Consent: This was a retrospective study and informed consent was not performed.

Peer-review: Externally peer-reviewed.

\section{Authorship Contributions}

Surgical and Medical Practices: M.I.G., E.S., Concept: M.I.G., Ç.A., Design: M.I.G., A.S., E.S., Data Collection or Processing: M.i.G., V.T.S., Analysis or Interpretation: M.I.G., A.S., Literature Search: M.I.G., A.A., Writing: M.I.G., E.S.

Conflict of Interest: No conflict of interest was declared by the authors.

Financial Disclosure: The authors declared that this study received no financial support. 


\section{References}

1. Scales CD Jr, Smith AC, Hanley JM, Saigal CS, Urologic Diseases in America Project. Prevalence of kidney stones in the United States. Eur Urol 2012;62:160-165.

2. Knoll T, Bach T, Humke U, Neisius A, Stein R, Schönthaler M, Wendt-Nordahl G. [S2k guidelines on diagnostics, therapy and metaphylaxis of urolithiasis (AWMF 043/025) : Compendium]. Urologe A 2016;55:904-922.

3. Assimos D, Krambeck A, Miller NL, Monga M, Murad MH, Nelson CP, Pace KT, Pais VM Jr, Pearle MS, Preminger GM, Razvi H, Shah O, Matlaga BR. Surgical Management of Stones: American Urological Association/Endourological Society Guideline, PART II. J Urol 2016;196:1161-1169.

4. Türk C, Petrík A, Sarica K, Seitz C, Skolarikos A, Straub M, Knoll T. EAU Guidelines on Interventional Treatment for Urolithiasis. Eur Urol 2016;69:475-482.

5. Donaldson JF, Lardas M, Scrimgeour D, Stewart F, MacLennan S, Lam TB, McClinton S. Systematic review and meta-analysis of the clinical effectiveness of shock wave lithotripsy, retrograde intrarenal surgery, and percutaneous nephrolithotomy for lower-pole renal stones. Eur Urol 2015;67:612-616.

6. Elbir $F$, Başıbüyük $\mathrm{I}$, Topaktaş $\mathrm{R}$, Kardaş $\mathrm{S}$, Tosun $\mathrm{M}$, Tepeler $\mathrm{A}$, Armağan A. Flexible ureterorenoscopy results: Analysis of 279 cases. Turk J Urol 2015;41:113-118.

7. $\mathrm{Ng} \mathrm{CF}$, Wong A, Tolley D. Is extracorporeal shock wave lithotripsy the preferred treatment option for elderly patients with urinary stone? A multivariate analysis of the effect of patient age on treatment outcome. BJU Int 2007;100:392-395.

8. Kanao K, Nakashima J, Nakagawa K, Asakura H, Miyajima A, Oya M, Ohigashi T, Murai M. Preoperative nomograms for predicting stone-free rate after extracorporeal shock wave lithotripsy. J Urol 2006;176:1453-1456.
9. Abdel-Khalek M, Sheir K, Elsobky E, Showkey S, Kenawy M. Prognostic factors for extracorporeal shock-wave lithotripsy of ureteric stones--a multivariate analysis study. Scand J Urol Nephrol 2003;37:413-418.

10. Gökce MI, Esen B, Gülpınar B, Süer E, Gülpınar Ö. External Validation of Triple D Score in an Elderly ( $\geq 65$ Years) Population for Prediction of Success Following Shockwave Lithotripsy. J Endourol 2016;30:1009-1016.

11. Tran TY, McGillen $K$, Cone EB, Pareek G. Triple D Score is a reportable predictor of shockwave lithotripsy stone-free rates. J Endourol 2015;29:226-230.

12. Wiesenthal JD, Ghiculete D, Ray AA, Honey RJ, Pace KT. A clinical nomogram to predict the successful shock wave lithotripsy of renal and ureteral calculi. J Urol 2011;186:556-562.

13. Abdel-Khalek M, Sheir KZ, Mokhtar AA, Eraky I, Kenawy M, Bazeed M. Prediction of success rate after extracorporeal shock-wave lithotripsy of renal stones--a multivariate analysis model. Scand J Urol Nephrol 2004;38:161-167.

14. Ichiyanagi 0 , Nagaoka A, Izumi T, Kawamura Y, Kato T. Age-related delay in urinary stone clearance in elderly patients with solitary proximal ureteral calculi treated by extracorporeal shock wave lithotripsy. Urolithiasis 2015;43:419-426.

15. Gokce MI, Tokatli Z, Suer E, Hajiyev P, Akinci A, Esen B. Comparison of shock wave lithotripsy (SWL) and retrograde intrarenal surgery (RIRS) for treatment of stone disease in horseshoe kidney patients. Int Braz J Urol 2016;42:96-100.

16. Abe T, Akakura K, Kawaguchi M, Ueda T, Ichikawa T, Ito H, Nozumi K, Suzuki K. Outcomes of shockwave lithotripsy for upper urinary-tract stones: a large-scale study at a single institution. J Endourol 2005;19:768-773.

17. Kimura M, Sasagawa T. [Significance of age on prognosis in patients treated by extracorporeal shock wave lithotripsy]. Nihon Hinyokika Gakkai Zasshi 2008;99:571-577.

18. Dhar NB, Thornton J, Karafa MT, Streem SB. A multivariate analysis of risk factors associated with subcapsular hematoma formation following electromagnetic shock wave lithotripsy. J Urol 2004;172:2271-2274. 